\title{
Validity and Practicality of Guided Inquiry-Based E-Modules accompanied by Virtual Laboratory to Empower Critical Thinking Skills
}

\author{
Natalia Dwiasty Ravista1, Sutarno ${ }^{2 *}$, Harlita $^{3}$ \\ ${ }^{1}$ Master of Biology Education, Postgraduate School, Universitas Sebelas Maret, Indonesia \\ ${ }^{2}$ Department of Biology, Faculty of Mathematics and Natural Science, Universitas Sebelas Maret, Indonesia \\ ${ }^{3}$ Department of Biology Education, Faculty of Teacher Training and Education, Universitas Sebelas Maret, Indonesia
}

DOI: $10.29303 /$ jppipa.v7iSpecialIssue.1083

\section{Article Info}

Received: November 1st, 2021

Revised: December $16^{\text {th }}, 2021$

Accepted: December 20th, 2021

\begin{abstract}
This study aims to determine the validity and practicality of guided inquirybased e-modules accompanied by virtual laboratories on digestive system materials to empower critical thinking skills. The type of research used is research and development (R\&D), by applying the Borg and Gall development model consisting of 10 steps and grouped in four stages including: preliminary study stage, development, testing, and deployment. This study is limited to e-modules validity and practicality testing. The instruments used are the validity and practicality questionnaires. The assessment of the results of the validity and practicality questionnaire is interpreted with the likert scale. Based on the analysis of the data obtained the following results: 1) Test validity by material experts, learning device experts, media experts, and education practitioners obtained a value in a row that is, $85.30 \%, 95.40 \%, 88.30 \%$, and $93.20 \%$ with very good category, 2) Practicality tests by small-scale student groups, large-scale student groups, and biology teachers from 3 schools obtained consecutive grades, i.e., $87.60 \%, 89.50 \%$, and $90.00 \%$ with very good category. Based on the validity and practicality tests, it can be concluded that the e-modules developed are valid and practical to use.
\end{abstract}

Keywords: E-Modules; Guided Inquiry; virtual laboratory; critical thinking skills; digestive system

Citation: Ravista, N., Sutarno., \& Harlita. (2021). Validity and Practicality of Guided Inquiry-Based E-Modules accompanied by Virtual Laboratory to Empower Critical Thinking Skills. Jurnal Penelitian Pendidikan IPA, 7(SpecialIssue), 331-339. https://doi.org/10.29303/jppipa.v7iSpecialIssue.1083

\section{Introduction}

Critical thinking skills are an essential objective of the education system as a form of participation in $21^{\text {st-century }}$ scholarly society to produce the next generation ready to face the growing demands of employment (Ching \& Fook, 2013; Kavenuke, et al., 2020; Shaw, et al., 2019). Critical thinking is the activity of thinking by utilizing the intellectual ability to conduct investigations, make the right judgments and decisions, and implement them appropriately (Setiawati \& Corebima, 2017). Critical thinking means thinking logically in problem-solving by analyzing situations, evaluating arguments, and drawing appropriate conclusions to increase the possible desired outcomes (Johan, 2013; Lloyd \& Bahr, 2010; Shaw, et al., 2019). Biology is one of the sciences intended to prepare the future of students who are critical, creative, competitive, and able to take decisions and solve problems appropriately (Aktamiş \& Yenice, 2010; Sudarisman, 2015). Based on a preliminary study conducted by researchers at SMAK Baleriwu Danga, Flores, NTT, students' critical thinking skills in biological sciences is low, with an average of $48.60 \%$.

Biological materials are often viewed as complex subjects. Çimer (2012) explained some of the things that 
make biology challenging to learn: 1) Biological materials have complex concepts and problems that must learn 2) Abstract and use many foreign languages. Henno \& Reiska (2008) explained that biological materials considered difficult are materials related to internal organs, organ systems, and the mechanisms in the body's organs, one of them is the digestive system material studied in class XI. It corresponds with the preliminary study in SMAK Baleriwu Danga, where some students reveal difficulty understanding digestive system materials concepts. The lower understanding of student concepts can indicate that students' critical thinking skills in digestive system materials are also relatively low. It is because of understanding concepts can be abstracted as a basis for acquiring the critical thinking skills.

Critical thinking skills in teaching are assumed to be a competency that can be achieved by a person and are constantly evolving (Nickerson in Kartimi, 2012). Therefore, teachers play an essential role in empowering students' critical thinking skills through a learning process that can train students to discover concepts independently (Patonah, 2014). Learning devices are an essential element as a determinant of learning success (Tanjung \& Nababan, 2018), and one of them is teaching materials. Therefore, innovation in the use of teaching materials needs to be improved by using electronic teaching materials or e-modules to empower students' critical thinking skills. Due to the demands of the 2013 curriculum, it must use technology in the learning process to improve the efficiency and effectiveness of learning (Sugianto et al., 2017).

E-Modules are digital teaching material that systematically presents material to facilitate students learning independently (Fausih \& Danang, 2015). EModules not only gives the material in the form of text but can combine with animations, videos, audio, images, and formative quizzes that can provide feedback automatically to motivate students to learn (Saputra \& Razak, 2020; Suarsana \& Mahayukti, 2013; Tazkiyah, et al., 2020). A good e-modules should be able to facilitate students to investigate the problems contained in the e-modules. Therefore, e-modules can develop by integrating the learning model as the basis for e-modules development (Kurniawan, 2013). A learning model that can be used for e-modules development to empower critical thinking skills is guided inquiry. Hermansyah, et al. (2019) explain that guided inquiry engages students with discovery-based learning and acts like scientists, which include: 1) asking questions about the world around them; 2) conducting experiments; 2) collecting and analyzing data; 3) Formulate and evaluating hypotheses. González, et al. (2015) defines guided inquiry as a teacher-guided learning model as an instructional team enhancing students' deep understanding and perspective through various information sources. According to Eggen \& Kauchak (2012), guided inquiry can assist students in understanding scientific methods that can develop critical thinking skills, self-regulation, and an understanding of a particular topic.

Guided inquiry is inseparable from experimental activities to solve problems, but not all schools have laboratory facilities to support practical activities. In addition, time constraints are also the factors of experimental activities that cannot be implemented, so the alternative to overcome this problem is to use a virtual laboratory. A virtual laboratory is a computer technology that supports conventional practicums by simulating laboratory experiments into a computer (Abdjul \& Ntobuo, 2018; Agustine, et al., 2014; Guimarães, et al., 2011; Oidov, et al., 2012). Virtual laboratories serve as a medium that can assist students in pre-lab preparation, build an understanding of abstract concepts, and complement natural laboratories where students can perform simulations repeatedly on parts that are not yet understood (Hawkins \& Phelps, 2013).

Based on the background above, it is necessary to research by developing a guided inquiry-based emodules accompanied by a virtual laboratory on digestive system materials to empower students' critical thinking skills.

\section{Method}

The type of research used is research and development (R\&D) by applying the Borg \& Gall (2003) development model consisting of 10 steps and grouped in 4 stages: preliminary study stage, development, testing, and deployment. The preliminary study phase consists of 2 steps, namely: 1) Research and information collecting. In this step, material analysis is carried out through literature studies and analysis of the needs of teachers and students through field surveys to find out problems related to the learning process at SMAK Baleriwu, 2) Planning. In this step, information is collected regarding the preparation of e-modules based on the problems that have been analyzed in the previous step.

The development phase consists of 5 steps, namely: 1) Development preliminary form of the product. In this step, the preparation and development of e-modules are adjusted to the guided inquiry syntax and accompanied by a virtual laboratory, 2) Premilinary field testing. In this step, the e-modules was validated by three expert lecturers from Sebelas Maret University: material experts, learning device experts, and media experts, and one teacher of SMAK 
Baleriwu Danga Flores, NTT as an education practitioner, 3) Main product revision. In this step, the correction of the phase 1 product is carried out based on input from experts and practitioners, 4) Main field testing. In this step, a small-scale practicality was tested on 10 students of class XII SMAK Baleriwu Danga who had obtained digestive system materials, 5) Operational product revision. In this step, a phase 2 product revision is carried out based on input provided by a small-scale group of students.

The testing phase consists of 2 steps, namely: 1) Operational field testing. In this step, a large-scale emodule practicality test was conducted by 22 students of class XI IPA 1 SMAK Baleriwu Danga. Students assessed e-modules after using e-modules in the learning process, 2) Final Product Revision. In this step, the final product revision. The spread stage is the last. At this stage, e-module is disseminated and implemented to 3 schools: SMAK ST. Teresia Danga, SMAS ST. Clemens Boawae and SMAK Stela Maris Danga. Furthermore, a practicality test was conducted by teachers from each school.

This research is limited to the validity process and practicality of the e-modules. The instruments used are the validity and practicality questionnaires. The suspension on the validity and practicality questionnaire based on the likert scale showed in Table 1.

Table 1. Likert scale

\begin{tabular}{ll}
\hline Answer Options & Score \\
\hline Not very good & 1 \\
Not good & 2 \\
Good & 3 \\
Very good & 4 \\
\hline
\end{tabular}

(Riduwan, 2010)

Data obtained from the results of validity and practicality questionnaires are then analyzed using the ${ }^{1}$ following formulas:

$$
\mathrm{P}=\frac{\sum x_{1}}{\sum x} \times 100 \%
$$

Information:

$\mathrm{P} \quad=$ Percentage rating

$\sum x_{i}=$ Score given by expert validators

$\sum x=$ Maximum score

The obtaining percentage results are interpreted into several categories shown in Table 2.

Table 2. Likert scale interpretation

\begin{tabular}{ll}
\hline Score $(\%)$ & Category \\
\hline $0-25$ & Not very good \\
$26-50$ & Not good \\
$51-75$ & Good \\
$76-100$ & Very good \\
\hline
\end{tabular}

(Riduwan, 2010)
In the development process, guided inquiry-based emodules with virtual laboratories is valid and practical if they obtain a value with a minimum category of "Good".

\section{Result and Discussion}

\section{Preliminary Study Stage}

The preliminary study stage consists of 2 steps. The research and information collecting step includes literature studies and field surveys. Literature studies are conducted to determine the material used as emodule content. According to BSN, the UN results in 2018/2019 showed that the absorption percentage of students at SMAK Baleriwu Danga in digestive system material is relatively low, 38,915 at the district level. Therefore, digestive system material is designated as emodule content.

The field survey was conducted to find out the problems related to the learning process at SMAK Baleriwu Danga. Based on the results of research conducted by Ravista, et al. (2021), there were several issues at SMAK Baleriwu Danga related to the learning process: 1) Teachers have applied several learning methods such as lectures and discussions but have not used innovative learning models that can empower students' critical thinking skills; 2) Teachers rarely conduct experimental activities, especially on the digestive system material. It is due to the limitation of laboratory facilities and time; 3 ) The teaching materials used are still conventional (printed), where the material presented is outlining concepts so as not to facilitate students with discovery activities and train for scientific thinking; 4) The evaluation problem contained in the teaching material is only remembering, so it has not empowered critical thinking skills.

Planning

The planning step consists of several activities, namely: 1) Determining the learning objectives of the emodule; 2) Determine the sub-subject matter of the digestive system; 3) Determine the format and visualization of the contents of the e-modules; 4) Determine the format of the learning device for the implementation of e-modules (syllabus, RPP, critical thinking evaluation questions, as well as validity and practicality questionnaires).

\section{Development Stage}

The development stage consists of 5 steps as follows:

1. Development preliminary form of the product.

In this step, the development of e-modules according to the guided inquiry syntax and equipped with a virtual laboratory to facilitate students in conducting experiments. The first step in developing e- 
modules is to create components contained in the emodules such as material text, images, videos, critical thinking problems, and virtual laboratory design. Furthermore, all details are put together with the help of Adobe Flash CS3 Professional software with exe format. The e-modules can only be accessed through computers with an offline system. This development is also based on previous research by Hakim (2014) related to e-modules. The e-modules display can be viewed as follows.

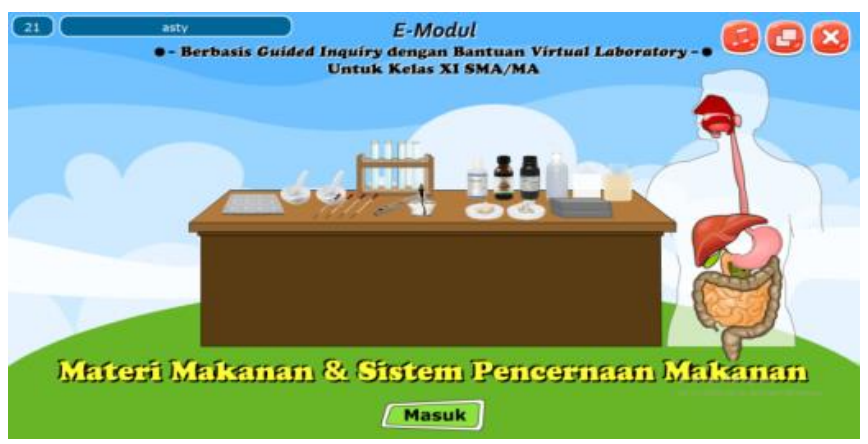

Figure 1. E-Modules start

Figure 1. is an e-modules title page display designed with interest and related to the material of the digestive system. On the title page is set the entry button to start the use of the e-modules.

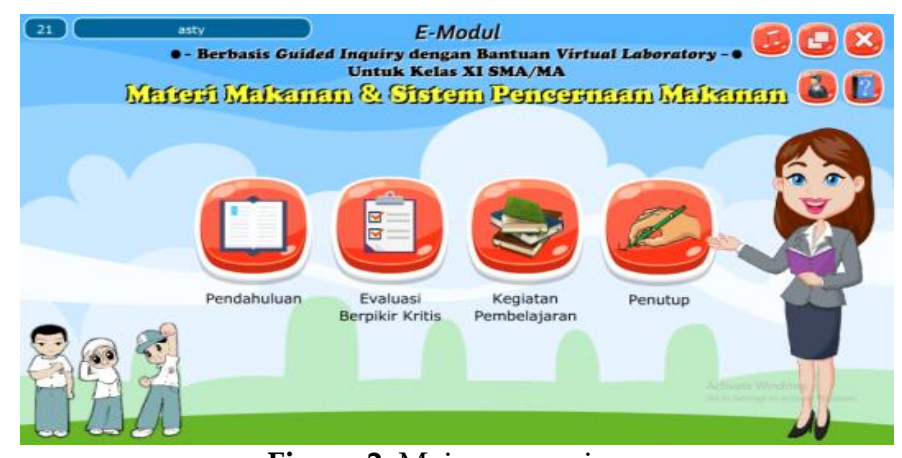

Figure 2. Main menu view

Figure 2. is the main menu display that appears when pressing the enter button on the title page. A navigation button on the main menu includes an introduction, critical thinking evaluation, learning activities, and closing.

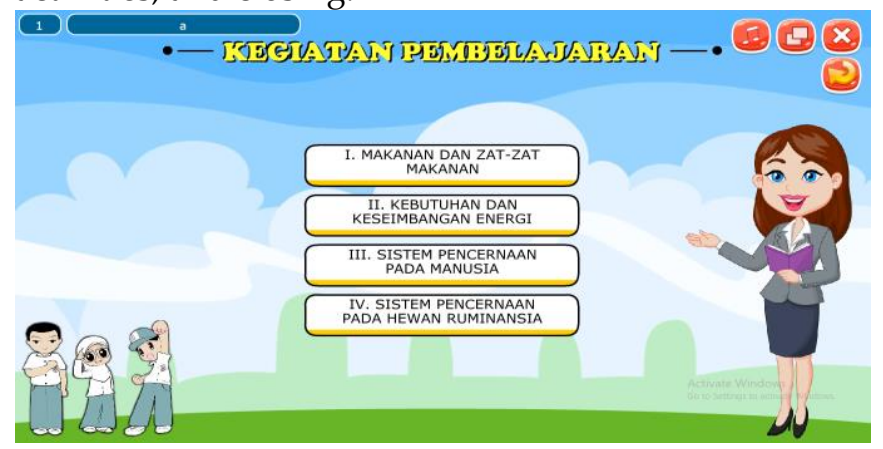

Figure 3. Digestive system material view
Figure 3. displays digestive system materials that students must learn, including 1) Food and food substances; 2) Energy needs and balance; 3) The human digestive system; 4) the Digestive system in ruminant animals.

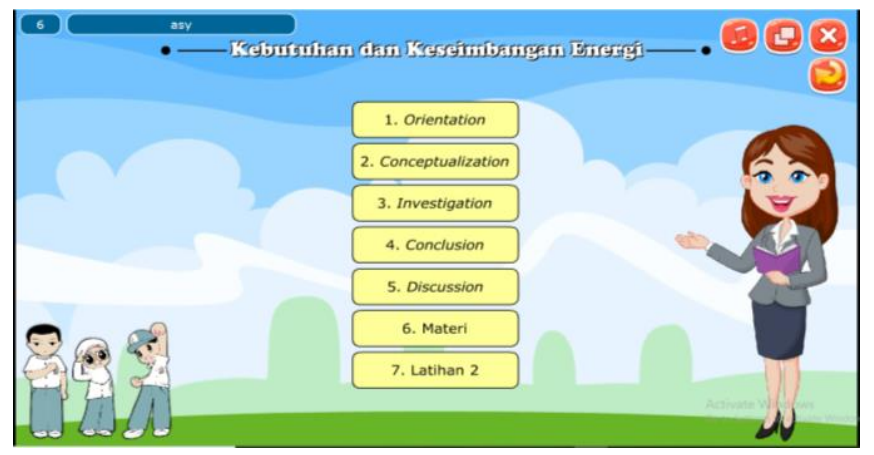

Figure 4. Guided inquiry syntax

Figure 4. is a guided inquiry syntax display used as the basis for e-modules development. The guided inquiry syntax refers to Pedaste, et al. (2015), including orientation, conceptualization, investigation, conclusion, and discussion. Each digestive system material is studied by following the guided inquiry syntax. The investigation stage will be equipped with a virtual laboratory to conduct experimental activities.

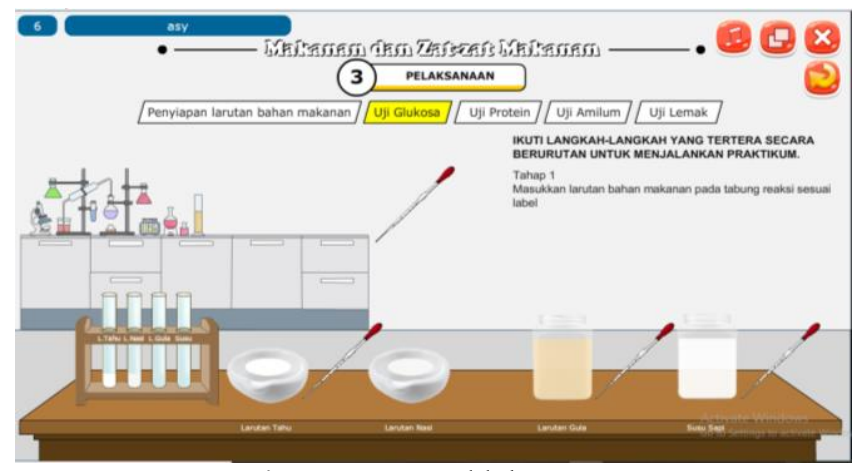

Figure 5. Virtual laboratory

Figure 5. is a virtual laboratory display that helps students to conduct experimental activities. Virtual laboratories enable more efficient practical exercises and positively impact understanding student concepts (Faour \& Ayoubi, 2017).

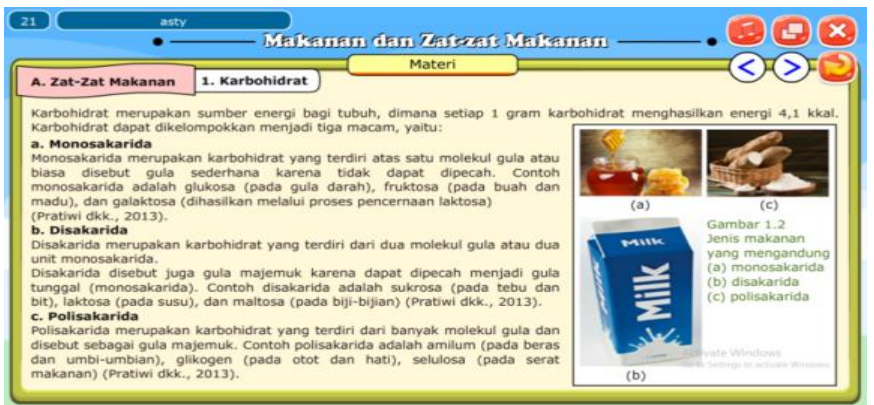

Figure 6. Summary of material 
Figure 6 . is a summary view of the material that comes with an image to clarify the concept.

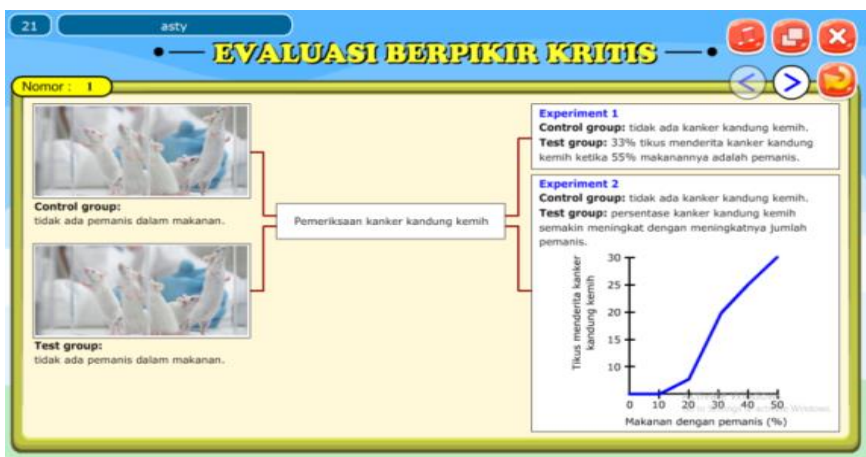

Figure 7. Question of critical thinking

Figure 7. is a question of critical thinking in the form of essays. Critical thinking consists of 6 numbers that are adjusted to indicators of critical thinking skills, according to Facione (2015), including interpretation, analysis, inference, evaluation, explanation, and selfregulation.

\section{Preliminary field testing}

In this step, e-modules validation was carried out by three lecturers of Sebelas Maret University consisting of: material experts, media experts, and learning device experts, as well as one biology teacher as an education practitioner, to obtain assessment and advice. It considers with Nieveen (2007) statement that the validity of a product is based on experts' assessment. The results of validation by the material expert are shown in Table 3.

Table 3. Validation of material expert

\begin{tabular}{lll}
\hline Aspects & $\begin{array}{l}\text { Percentage } \\
(\%)\end{array}$ & Category \\
\hline Content eligibility & 89.50 & Very good \\
Presentation eligibility & 83.30 & Very good \\
Language eligibility & 83.30 & Very good \\
Average & 85.30 & Very good \\
\hline
\end{tabular}

Table 3. shows an average score by material experts of $85.30 \%$. The eligibility aspect of the contents obtained a score of $89.50 \%$. It proves that the material in the e-modules has adapted to basic competency and competency standards, is accurate and contains components that can encourage student curiosity. Emodules equipped with essential competencies, indicators of competency achievement, and learning goals that must be achieved will be easy to use (Depdiknas, 2008).

Aspects of presentation eligibility obtained a score of $83.30 \%$. It proves that e-modules consist of complete components to facilitate student involvement in the learning process. The developed e-modules are structured based on a guided inquiry syntax that makes learning student-centered.

Aspects of language eligibility obtained a score of $83.30 \%$. It proves that the language used in the preparation of e-modules is straightforward and communicative. The use of communicative sentences can increase students' learning interest (Hamdani, 2011). Based on data analysis, the material packaged in the e-modules are valid with several revisions. Meanwhile, the validation results by media experts are shown in Table 4.

Table 4. Validation of media expert

\begin{tabular}{lll}
\hline Aspects & $\begin{array}{l}\text { Percentage } \\
(\%)\end{array}$ & Category \\
\hline E-modules view & 92.50 & Very good \\
Programming & 93.70 & Very good \\
Code of ethics and copyright & 100.00 & Very good \\
Average & 95.40 & Very good \\
\hline
\end{tabular}

Table 4. shows an average score by media experts of $95.40 \%$. The view aspect of the e-modules obtained a score of 92.50 This proves that the emodules has the right cover and back sound design, attractive navigation buttons, and the right size, colour, and typeface. Beautiful design and audio can increase students' motivation and creativity (Hamdani, 2011).

The programming aspect obtained a score of $93.70 \%$. It proves that the use of e-modules runs smoothly and flexibly. Aspects of the code of ethics and copyright obtained a score of $100.00 \%$. It proves that emodules are equipped with citations and bibliography to avoid plagiarism. Based on data analysis, the presentation of e-modules is declared valid with several revisions. At the same time, the results of expert validation of learning devices are shown in Table 5 .

Table 5. Validation of learning devices expert

\begin{tabular}{lll}
\hline Aspects & $\begin{array}{l}\text { Percentage } \\
(\%)\end{array}$ & Category \\
\hline Syllabus & 100.00 & Very good \\
RPP & 83.30 & Very good \\
Question of critical thinking & 81.60 & Very good \\
skills & & \\
Average & 88.30 & Very good \\
\hline
\end{tabular}

Table 5. shows an average score by a learning device expert of $88.30 \%$. Therefore, learning devices that include syllabuses, RPP, and critical thinking skills to support the implementation of e-modules are declared valid with some revisions. At the same time, the results of validation by practitioners can be seen in Table 6. 
Table 6. Validation of educational practitioners

\begin{tabular}{lll}
\hline Aspect & $\begin{array}{l}\text { Percentage } \\
(\%)\end{array}$ & Category \\
\hline Content eligibility & 95.80 & Very good \\
Presentation eligibility & 88.80 & Very good \\
Language eligibility & 96.80 & Very good \\
Usage and durability & 91.60 & Very good \\
Average & 93.20 & Very good \\
\hline
\end{tabular}

Table 6. shows an average score by education practitioners of $93.20 \%$. The aspects assessed by education practitioners are the same as those observed by material experts, and the score for all elements falls into the excellent categories. However, there is one additional aspect, namely usage and durability with a score of $91.60 \%$. It proves that e-modules are easy to use and can be stored for long periods. Therefore, the emodules are declared valid with some revisions.

\section{Main product revision}

Based on the results of validation by experts and education practitioners obtained some advice for the improvement of e-modules. Suggestions and revised results from expert and practitioner validators are shown in Table 7.

Table 7. Suggestions and revisions from expert validators and practitioners

\begin{tabular}{|c|c|c|}
\hline Validator & Suggestion & Revision \\
\hline \multirow[t]{4}{*}{ Materials expert } & $\begin{array}{l}\text { Add essential and non-essential amino acid- } \\
\text { related materials in table form }\end{array}$ & $\begin{array}{l}\text { Material related to the difference between } \\
\text { essential and non-essential amino acids has been } \\
\text { added in the form of tables }\end{array}$ \\
\hline & $\begin{array}{l}\text { Make a table of differences in water-soluble } \\
\text { vitamins and fats, along with examples of their } \\
\text { sources. }\end{array}$ & $\begin{array}{l}\text { A table of differences in water-soluble vitamins } \\
\text { and fats, along with examples of their sources } \\
\text { have been added. }\end{array}$ \\
\hline & Improve explanation of goblet cell function & $\begin{array}{l}\text { Explanation of goblet cell function has been } \\
\text { corrected. }\end{array}$ \\
\hline & $\begin{array}{l}\text { Material related to dental formulas needs to be } \\
\text { added to be easy to understand }\end{array}$ & $\begin{array}{l}\text { Material related to the dental formula has been } \\
\text { added }\end{array}$ \\
\hline \multirow[t]{2}{*}{ Media expert } & $\begin{array}{l}\text { In each column, demanding answers, students } \\
\text { must be given a number and line of dots. } \\
\text {-At the orientation stage, the images presented } \\
\text { can use personal documentation to increase } \\
\text { originality. }\end{array}$ & $\begin{array}{l}\text { Columns demanding students' answers are } \\
\text { equipped with numbers and dot lines. } \\
\text { Images at the orientation stage are presented } \\
\text { using personal documentation. }\end{array}$ \\
\hline & $\begin{array}{l}\text { In each sub-material and learning syntax must } \\
\text { be assigned a number }\end{array}$ & $\begin{array}{l}\text { In each sub-material and learning syntax has } \\
\text { been given a number }\end{array}$ \\
\hline Learning device expert & $\begin{array}{l}\text { Learning goals should be made with the } \\
\text { ABCD formula (Audience, Behavior, } \\
\text { Condition, Degree) }\end{array}$ & $\begin{array}{l}\text { Learning objectives have been improved using } \\
\text { the ABCD (Audience, Behavior, Condition, } \\
\text { Degree) formula. }\end{array}$ \\
\hline Education practitioners & $\begin{array}{l}\text { In the virtual laboratory, especially in protein } \\
\text { content tests, there are errors in discolouration } \\
\text { after reagent testing. }\end{array}$ & $\begin{array}{l}\text { Discolouration in protein tests has been } \\
\text { corrected. }\end{array}$ \\
\hline
\end{tabular}

\section{Main field testing}

In this step, practicality tests are carried out to determine the practicality of using e-modules in the field. Small-scale student groups conduct practicality tests $(\mathrm{n}=10)$, students of class XII IPA SMAK Baleriwu Danga obtained digestive system materials. It considers with Nieveen (2007) statement that the product's practicality is obtained from the results of teacher and student assessments in the learning process to consider products developed easily used or not. The results of practicality tests by small-scale groups of students are shown in Table 8.
Table 8. Practicality tests by small-scale groups of students

\begin{tabular}{lcl}
\hline \multicolumn{1}{c}{ Aspect } & $\begin{array}{c}\text { Percentage } \\
(\%)\end{array}$ & \multicolumn{1}{c}{ Category } \\
\hline Material & 87.00 & Very good \\
E-module view & 88.90 & Very good \\
Language & 87.70 & Very good \\
Usage and durability & 90.80 & Very good \\
Average & 87.60 & Very good \\
\hline
\end{tabular}

Table 8 . shows an average score by a small-scale group of students of $87.60 \%$. Aspects of the material obtained a score of $87.00 \%$, which proved students can understand the material quickly. The view aspect of the e-modules received a score of $88.90 \%$, which confirmed the e-modules has an attractive look. The language 
aspect scored $87.70 \%$, which proved students quickly understood the language used in the e-modules. Aspects of usage and durability obtained a score of $90.80 \%$, which proved students can use e-modules easily. Based on data analysis, the e-modules are declared practical for use with multiple revisions.

\section{Operational product revision}

Based on the results of practicality tests by smallscale student groups obtained some suggestions for the improvement of e-modules. Suggestions and revised results from a small group of students are shown in Table 9.

Table 9. Suggestions and revisions by small-scale student groups

\begin{tabular}{ll}
\hline Suggestions & Revisions \\
\hline $\begin{array}{l}\text { The e-Module is presented } \\
\text { attractively and comes with }\end{array}$ & $\begin{array}{l}\text { The wrong word has been } \\
\text { corrected. }\end{array}$ \\
$\begin{array}{l}\text { a clear description, but } \\
\text { must bect word writing still }\end{array}$ & \\
must bected. & \\
\hline
\end{tabular}

Testing Stage

The stage consists of 2 steps as follows:

1. Operational field testing

In this step, practicality tests are carried out to determine the practicality of using e-modules in the field. A large-scale group of students conducted the practicality test $(n=22)$, namely class XI IPA 1 SMAK Baleriwu Danga students. The results of practicality tests by large-scale groups of students are shown in Table 10.

Table 10. Practicality test by large-scale student groups

\begin{tabular}{lcl}
\hline \multicolumn{1}{c}{ Aspect } & $\begin{array}{c}\text { Percentage } \\
(\%)\end{array}$ & Category \\
\hline Material & 88.60 & Very good \\
E-module view & 90.70 & Very good \\
Language & 88.60 & Very good \\
Usage and durability & 90.00 & Very good \\
Average & 89.50 & Very good \\
\hline
\end{tabular}

Table 10. shows an average score by a large-scale group of students of $89.50 \%$. Based on the data, largescale student groups' acquisition of practicality test scores increases more than practicality tests by smallscale student groups. It proves that the advice given in the previous step can improve the quality of the emodules. Therefore, e-modules are otherwise practical to use.

\section{Final product revision}

In this step, there are no improvements to the emodules. Based on the student responses, the e- modules developed are very good and exciting to increase learning spirit and interest. Therefore, emodules can be used in the field without revision.

\section{Deployment Stage}

At this stage, dissemination and implementation are carried out. The e-modules developed are distributed to 3 nearby schools, namely SMAK ST. Teresia Danga, SMAS ST. Clemens Boawae, and SMAK Stela Maris Danga. Furthermore, one biology teacher from each school conducted the practicality test to find out the practicality of using e-modules in the field. The results of the practicality test by the teacher are shown in Table 11.

Table 11. Practicality tests by teachers

\begin{tabular}{lll}
\hline Aspect & $\begin{array}{l}\text { Percentage } \\
(\%)\end{array}$ & Category \\
\hline Content eligibility & 88.00 & Very good \\
Presentation eligibility & 91.60 & Very good \\
Language eligibility & 90.50 & Very good \\
Usage and durability & 89.90 & Very good \\
Average & 90.00 & Very good \\
\hline
\end{tabular}

Table 11. shows an average score by teachers of $90.00 \%$. Each aspect is assessed to have a very good category score. Therefore, e-modules are otherwise practical to use. In addition, dissemination and implementation steps are also carried out by disseminating products in scientific journals.

\section{Conclusion}

Based on the research that has been done, it can be said that the inquiry-based e-modules accompanied by a virtual laboratory on digestive system material is valid and practical. Suggestions obtained from expert validators, teachers, and students can improve the quality of the developed e-modules to be suitable for use in the learning process.

\section{Acknowledgements}

Thank you to all those who have participated in this research, especially to the principal, teacher, and students of SMAK Baleriwu Danga, Flores, NTT, who have helped so that this research can run well.

\section{References}

Abdjul, T., \& Ntobuo, N. (2018). Developing Device of Learning Based on Virtual Laboratory through Phet Simulation for Physics Lesson with Sound Material. International Journal of Sciences: Basic and Applied Research (IJSBAR), 39(2), 105-115. 
Retrieved

from:http://gssrr.org/index.php?journal=Journ alOfBasicAndApplied

Agustine, D., Wiyono, K., \& Muslim, M. (2014). Pengembangan e-learning berbantuan virtual laboratory untuk mata kuliah praktikum fisika dasar ii di program studi pendidikan fisika fkip unsri. Jurnal Inovasi Dan Pembelajaran Fisika, 1(1), 33-43. https://doi.org/10.36706/jipf.v1i1.1218 [Indonesian]

Aktamiş, H., \& Yenice, N. (2010). Determination of the science process skills and critical thinking skill levels. Procedia - Social and Behavioral Sciences, 2(2),

3282-3288. https://doi.org/10.1016/j.sbspro.2010.03.502

Borg, W. R., \& Gall, J. P. (2003). Educational Research and Introduction. United Stated of America: Library of Congress Cataloging in Publication Data.

Ching, H. S., \& Fook, F. S. (2013). Effects of Multimedia Based Graphic Novels. The Turkish Online Journal of Educational Technology, 12(4), 56-66.

Çimer, A. (2012). What Makes Biology Learning Difficult and Effective: Students' Views. Educational Research and Reviews, 7(3), 61-71. doi: https://doi.org/10.5897/ERR11.205

Depdiknas. (2008). Panduan Pengembangan Bahan Ajar. Jakarta: Departemen Pendidikan Nasional [Indonesian]

Eggen, P., \& Kauchak, D. (2012). Strategies and Models for Teachers. Boston: Pearson. [Indonesian]

Facione, P. a. (2011). Critical Thinking: What It Is and Why It Counts. Insight Assessment, ISBN 13: 9781-891557-07-1., $1-28$. https://www.insightassessment.com/CT-...ItCounts-PDF.

Faour, M. A., \& Ayoubi, Z. (2017). The Effect of Using Virtual Laboratory on Grade 10 Students' Conceptual Understanding and their Attitudes towards Physics. Journal of Education in Science, Environment and Health, 4(1), 54-68. https://doi.org/10.21891/jeseh.387482

Fausih, M., \& Danang, T. (2015). Pengembangan Media E-Modul Mata Pelajaran Produktif Pokok Bahasan "Instalasi Jaringan Lan (Local Area Network)" Untuk Siswa Kelas Xi Jurusan Teknik Komputer Jaringan Di Smk Nengeri 1 Labang Bangkalan Madura. Jurnal UNESA, 01(01), 1-9. Retrieved from: https://jurnalmahasiswa.unesa.ac.id/index.php Ljmtp/article/view/10375 [Indonesian]

González, M., González, M., Martín, M. E., Llamas, C., Martínez, Ó., Vegas, J., Herguedas, M., \& Hernández, C. (2015). Teaching and learning physics with smartphones. Journal of Cases on
Information Technology, 17(1), 31-50. https://doi.org/10.4018/JCIT.2015010103

Guimarães, E., Cardozo, E., Moraes, D. H., \& Coelho, P. R. (2011). Design and implementation issues for modern remote laboratories. IEEE Transactions on Learning Technologies, 4(2), 149-161. https://doi.org/10.1109/TLT.2010.22

Hakim, L. (2014). Pengembangan Modul Elektronik Berbasis Problem Based Learning pada Materi Pencemaran Lingkungan untuk Memberdayakan Kemampuan Memecahkan Masalah (Unpublished master thesis), Universitas Sebelas Maret, Sirakarta [Indonesian]

Hamdani. (2011). Stategi Belajar Mengajar. Bandung: CV Pustaka. [Indonesian]

Hawkins, I., \& Phelps, A. J. (2013). Virtual laboratory vs. traditional laboratory: Which is more effective for teaching electrochemistry? Chemistry Education Research and Practice, 14(4), 516-523. https://doi.org/10.1039/c3rp00070b

Henno, I., \& Reiska, P. (2008). Using concept mapping as assessment tool in school biology. Paper presented at $3^{\text {rd }}$ International Conference on Concept Mapping, 3(1), 86-95. Retrieved from http://search.ebscohost.com/login.aspx?direct=. $. . \& \mathrm{crl}=\mathrm{c}$

Hermansyah, H., Gunawan, G., Harjono, A., \& Adawiyah, R. (2019). Guided inquiry model with virtual labs to improve students' understanding on heat concept. Paper presented 9th ICOPIA, Surakarta. $\quad$ https://doi.org/10.1088/17426596/1153/1/012116

Johan, H. (2013). Pengaruh Sscs Problem Solving Untuk Meningkatkan Keterampilan Berpikir Kritis Mahasiswa Pada Pembelajaran Konsep Listrik Dinamis. Jurnal Pendidikan Matematika Dan IPA, 4(1),

13-19.

https://doi.org/10.26418/ipmipa.v4i1.6202 [Indonesian]

Kartimi, dan L. (2012). Pengembangan Alat Ukur Berpikir Kritis Pada Konsep Senyawa Hidrokarbon Untuk Siswa SMA di Kabupaten Kuningan. Jurnal Pendidikan MIPA, 13(1), 18-25. Retrieved from: http://jurnal.fkip.unila.ac.id/index.php/jpm/ar ticle/view/397 [Indonesian]

Kavenuke, P. S., Kinyota, M., \& Kayombo, J. J. (2020). The critical thinking skills of prospective teachers: Investigating their systematicity, selfconfidence and scepticism. Thinking Skills and Creativity, 37, 100677. https://doi.org/10.1016/j.tsc.2020.10067

Kurniawan, A. D. (2013). Metode inkuiri terbimbing dalam pembuatan media pembelajaran biologi untuk meningkatkan pemahaman konsep dan 
kreativitas siswa SMP. Jurnal Pendidikan IPA Indonesia, 2(1), 8-11. https://doi.org/10.15294/jpii.v2i1.2503 [Indonesian]

Lloyd, M., \& Bahr, N. (2010). Thinking Critically about Critical Thinking in Higher Education. International Journal for the Scholarship of Teaching and Learning, 4(2). https://doi.org/10.20429/ijsotl.2010.040209

Nieveen. (2007). Formative Evaluation in Educational Design Research. London: Kluwer Academic Publisher.

Oidov, L., Tortogtokh, U., \& Purevdagva, E. (2012). Virtual laboratory for physics teaching. 2012 International Conference on Management and Education Innovation, 37, 319-323. Retrieved from http://www.ipedr.com/vol37/062-ICMEI2012E10015.pdf

Patonah, S. (2014). Elemen bernalar tujuan pada pembelajaran ipa melalui pendekatan metakognitif siswa SMP. Jurnal Pendidikan IPA Indonesia, 3(2), 128-133. https://doi.org/10.15294/jpii.v3i2.3111 [Indonesian]

Pedaste, M., Mäeots, M., Siiman, L. A., de Jong, T., van Riesen, S. A. N., Kamp, E. T., Manoli, C. C., Zacharia, Z. C., \& Tsourlidaki, E. (2015). Phases of inquiry-based learning: Definitions and the inquiry cycle. Educational Research Review, 14, 4761. https:// doi.org/10.1016/j.edurev.2015.02.003

Ravista, N. D., Sutarno, \& Harlita. (2021). An Analysis of the Need for Developing E-Module Based on Problem Based Learning Utilizing Virtual Laboratory on the Digestive System Material. Paper presented at $6^{\text {th }}$ ISSE, Yogyakarta. doi: https://doi.org/10.2991/assehr.k.210326.090

Riduwan. (2010). Skala Pengukuran Variabel-Variabel Penelitian. Bandung: Alfabeta. [Indonesian]

Saputra, R. R., \& Razak, A. (2020). Problem Analysis and Requirement of Biology Materials by EModule Based on Android in SMAN 3 Padang. International Journal of Progressive Sciences and Technologies, 20(1), 102-108. http://dx.doi.org/10.52155/ijpsat.v20.1.1689.

Setiawati, H., \& Corebima, A.D. (2017). Empowering Critical Thinking Skills Of The Students Having Different Academic Ability in Biology Learning of Senior High School through PQ4R - TPS Strategy. The International Journal of Social Sciences and Humanities Invention, 4(5), 3521-3526. https://doi.org/10.18535/ijsshi/v4i5.09

Shaw, A., Liu, O. L., Gu, L., Kardonova, E., Chirikov, I., Li, G., Hu, S., Yu, N., Ma, L., Guo, F., Su, Q., Shi, J., Shi, H., \& Loyalka, P. (2019). Thinking critically about critical thinking: validating the
Russian HEIghten ${ }^{\circledR}$ critical thinking assessment. Studies in Higher Education, 45(9), 1933-1948. https://doi.org/10.1080/03075079.2019.1672640

Suarsana, I.M., \& Mahayukti, G.A. (2013). Pengembangan e-modul berorientasi pemecahan masalah untuk meningkatkan keterampilan berpikir kritis mahasiswa. Jurnal Nasional Pendidikan Teknik Informatika, 2(3), 193-200. http://dx.doi.org/10.23887/jpiundiksha.v2i2.2171 [Indonesian]

Sudarisman, S. (2015). Memahami Hakikat Dan Karakteristik Pembelajaran Biologi Dalam Upaya Menjawab Tantangan Abad 21 Serta Optimalisasi Implementasi Kurikulum 2013. Florea: Jurnal Biologi Dan Pembelajarannya, 2(1), 29-35. https://doi.org/10.25273/florea.v2i1.403 [Indonesian]

Sugianto, D., Abdullah, A. G., Elvyanti, S., \& Muladi, Y. (2017). Modul Virtual: Multimedia Flipbook Dasar Teknik Digital. Innovation of Vocational Technology Education, 9(2), 101-116. https://doi.org/10.17509/invotec.v9i2.4860 [Indonesian]

Tanjung, H. S., \& Nababan, S. A. (2018). Pengembangan Perangkat Pembelajaran Matematika Berorientasi Model Pembelajaran Berbasis Masalah (PBM) Untuk Meningkatkan Kemampuan Berpikir Kritis Siswa Sma Se-Kuala Nagan Raya Aceh. Genta Mulia, 9(2), 56-70. Retrieved from: https://www.ejournal.stkipbbm.ac.id/index.ph $\mathrm{p} / \mathrm{gm} /$ article/view/168 [Indonesian]

Tazkiyah, A., Sulur, S., \& Fawaiz, S. (2020). Pengembangan Modul Elektronik Dengan Feedback Berbasis Android Materi Suhu Dan Kalor Untuk Siswa SMA/MA. Jurnal Pendidikan Fisika Dan Teknologi, 6(1), 31. https://doi.org/10.29303/jpft.v6i1.1731 [Indonesian] 